\title{
Bone and Heart Abnormalities of Subclinical Hyperthyroidism in Women Below the Age of 65 Years
}

\section{original article}

\author{
Pedro Weslley Rosario \\ Endocrinology Service, Santa \\ Casa de Belo Horizonte, \\ MG, Brazil.
}

The objective of the present study was to evaluate bone and cardiac abnormalities and symptoms and signs of thyroid hormone excess in women with subclinical hyperthyroidism ( $\mathrm{SCH}$ ) aged $<65$ years. Forty-eight women with $\mathrm{SCH}$ were evaluated. The control group consisted of 48 euthyroid volunteers. The mean symptom rating scale score was significantly higher in patients. Cardiac involvement, both morphological and affecting systolic and diastolic functions, was also observed in patients. Women with $\mathrm{SCH}$ showed a significant increase in serum markers of bone formation and resorption. In addition, bone mineral density (BMD) was lower in the femoral neck but not in the lumbar spine in patients before menopause, whereas a lower BMD was observed at both sites in postmenopausal patients. $\mathrm{SCH}$ is not completely asymptomatic in women aged $<65$ years, and is associated with heart abnormalities and with increased bone turnover and reduced BMD even before menopause. (Arq Bras Endocrinol Metab 2008; 52/9:1448-1451)

Keywords: Subclinical hyperthyroidism; Bone; Heart

\section{RESUMO}

\section{Anormalidades Ósseas e Cardíacas do Hipertireoidismo Subclínico em Mulheres} com menos de 65 Anos.

O objetivo deste estudo foi avaliar as anormalidades ósseas e cardíacas, sintomas e sinais de excesso de hormônio tireoidiano em mulheres com hipertireoidismo subclínico (HSC) e menos de 65 anos de idade. Quarenta e oito mulheres com HSC foram avaliadas. O grupo-controle consistiu de 48 voluntárias eutireoidianas. A média do escore de sintomas foi significativamente maior em pacientes que em controles. Comprometimento cardíaco, morfológico e afetando as funções sistólica e diastólica, também foi observado. Mulheres com HSC apresentaram significativo aumento dos marcadores séricos de formação e reabsorção óssea. A densidade mineral óssea (DMO) foi menor no colo de fêmur, mas não em coluna lombar em mulheres antes da menopausa; enquanto e em ambos os sítios nas mulheres pós-menopausadas. HSC não é inteiramente assintomático em mulheres com menos de 65 anos, está associado a anormalidades cardíacas morfológicas e funcionais, incremento da remodelação óssea, e menor DMO, mesmo antes da menopausa. (Arq Bras Endocrinol Metab 2008; 52/9:1448-1451)

Descritores: Hipertireoidismo subclínico; Osso; Coração

\section{INTRODUCTION}

ubclinical hyperthyroidism ( $\mathrm{SCH}$ ) is characterized by persistently reduced

TSH in the presence of normal T4 and T3, after excluding other causes of low TSH (1). SCH is associated with a higher risk of progression to overt hyperthyroidism, lower bone mineral density (BMD) in postmenopausal wo-
Received in 27/5/2008 Acepted in 28/8/2008 
men, cardiovascular abnormalities, and an increased frequency of atrial fibrillation (1). These repercussions have been well described for elderly individuals but the data are less consistent for patients aged $<60-65$ years, even when TSH $\leq 0.1 \mathrm{mIU} / \mathrm{l}(\mathrm{l})$. The purpose of the present study is to evaluate bone and cardiac abnormalities and symptoms and signs of thyroid hormone excess in women with endogenous SCH aged $<65$ years.

\section{SUBJECTS AND METHODS}

\section{Patients}

Forty-eight non-institutionalized women aged $<65$ years with $\mathrm{SCH}$ were evaluated. $\mathrm{SCH}$ was defined as the presence of persistent TSH levels $\leq 0.1 \mathrm{mIU} / \mathrm{l}$ (two consecutive measurements at an interval of 8 weeks) and normal free T4 and total T3, after excluding pregnancy, pituitary disease, psychiatric disease and medications that could interfere with serum TSH. The etiology of SCH was Graves' disease in 15 patients, nodular thyroid disease in 30 and no cause was defined in 3 . Non of the patients had previously overt hyperthyroidism or had received radioiodine or anti-thyroid drugs in the past. Excluded were patients with heart disease and arterial hypertension, patients treating osteoporosis and women using estrogen or corticosteroid. The control group consisted of 48 volunteers matching the patients in age, body mass index (BMI) and menopausal status (Table 1). The control subjects were in good general health, presented no clinical and/or biochemical evidence of thyroid disease and were not taking any medications. Patients and controls were nonsmokers.

The study was approved by the Ethics Committee of the institution and was not supported by research funds.

To evaluate the occurrence of specific symptoms and signs of thyroid hormone excess, patients and control subjects were assessed using the Symptom Rating Scale (SRS) (2). PTH, TSH, free T4 and total T3 were determined by an immunochemiluminescence assay with reference values of 12 to $65 \mathrm{pg} / \mathrm{ml}, 0.3$ to 5 $\mathrm{mIU} / 1,9.63$ to $23.17 \mathrm{pmol} / \mathrm{l}$ and 1.16 to $3.39 \mathrm{pmol} / \mathrm{l}$, respectively. Serum carboxyterminal telopeptide (CTx) was measured by an electrochemiluminescence assay (reference: pre-menopause, 0.025 to $0.573 \mathrm{ng} / \mathrm{ml}$ and postmenopause, 0.104 to $1.008 \mathrm{ng} / \mathrm{ml}$ ). Bone-specific alkaline phosphatase (BSAP) was determined by capture immunoassay (reference: women 25 to 55 years, 11.6 to $30.6 \mathrm{U} / 1$ and $>56$ years, 14.8 to $43.4 \mathrm{U} / \mathrm{l}$ ) and $25(\mathrm{OH})$ vitamin D was measured by HPLC (reference value: 14 to $80 \mathrm{ng} / \mathrm{ml}$ ). BMD was measured by dual energy x-ray absorptiometry (DEXA) in the femoral neck and lumbar spine (Ll-L4). Doppler echocardiography was used to measure left ventricular (LV) dimensions in the M-mode during end-systole and end-diastole. LV mass was calculated using the standard equation and indexed for body surface area (LVMi) (3). LV volumes and ejection fraction were calculated from two-dimensional echocardiographic apical view images during end-systole and end-diastole using the modified Simpson's rule biplane method. The following parameters were measured and calculated by mitral flow velocimetry: maximal early diastolic flow velocity $(\mathrm{E})$, maximal late diastolic flow velocity (A), and the $\mathrm{E} / \mathrm{A}$ ratio. Isovolumic relaxation time was obtained by simultaneous recording of aortic and mitral flow by continuous-wave Doppler at a speed of 100 $\mathrm{mm} / \mathrm{s}$. The investigators were unaware of which group the subject belonged to.

The two-tailed unpaired Student's t test, MannWhitney $U$ test and linear regression were used for statistical analysis. $\mathrm{P}$ less than 0.05 was considered significant. The calculations were performed using SPSS for Windows.

\section{RESULTS}

Symptom Rating Scale (SRS) score was significantly higher in patients with endogenous $\mathrm{SCH}$. Bone mineral density (BMD) was lower in the femoral neck but not in the lumbar spine in premenopause patients, whereas a lower BMD was observed on both sites in postmenopausal women with $\mathrm{SCH}$. Increase in markers of bone formation (BSAP) and resorption (CTx) were also observed. LVMi, ejection fraction, E/A ratio and isovolumic relaxation time were significantly different in patients with SCH. These results are shown in Table 1. No significant correlation was observed between the parameters studied and TSH or thyroid hormone levels.

\section{DISCUSSION)}

The finding of a mean SRS score, which evaluates specific symptoms and signs of hyperthyroidism, signifi- 
Table 1. Characteristics of the study population.

\begin{tabular}{|c|c|c|}
\hline & Patients $(n=48)$ & Controls $(n=48)$ \\
\hline Age (mean, years) & $35-63(52.9)$ & $36-62(53.1)$ \\
\hline Postmenopausal (\%) & $26(54)$ & $25(52)$ \\
\hline $\mathrm{BMI}\left(\right.$ mean, $\mathrm{kg} / \mathrm{m}^{2}$ ) & $19-30.5(27.2)$ & $19.2-31(27)$ \\
\hline $\mathrm{TSH}($ mean, mlU/I)** & $0.01-0.1(0.064)$ & $0.5-3.2(1.45)$ \\
\hline Free T4 (mean, pmol/I)* & $14.4-22.65(18.7)$ & $10.8-18(15.4)$ \\
\hline Total T3 (mean, pmol/l)* & $2.16-3.15(2.65)$ & $1.35-2.67(2.03)$ \\
\hline SRS (mean) $)^{\star *}$ & $5-13(9.0)$ & $3-8(4.2)$ \\
\hline LVMi $\left(\mathrm{g} / \mathrm{m}^{2}\right)^{* *}$ & $63-114(90)$ & $58-106(76)$ \\
\hline LV ejection fraction (mean, \%) ${ }^{\star *}$ & $42-64(54)$ & $40-56(46)$ \\
\hline E/A ratio** & $0.6-1.8(1.23)$ & $0.8-2.3(1.82)$ \\
\hline Isovolumic relaxation time (mean, $\mathrm{ms})^{* *}$ & $73-119(98)$ & $68-102(82)$ \\
\hline $\begin{array}{l}\text { Calcium (mean, } \mathrm{mg} / \mathrm{dl} \text { ) } \\
\text { Premenopausal } \\
\text { Postmenopausal }\end{array}$ & $\begin{array}{l}8.5-10(9.05) \\
8.5-10(9.15)\end{array}$ & $\begin{array}{l}8.5-10(9.15) \\
8.5-10(9.3)\end{array}$ \\
\hline $\begin{array}{l}\text { PTH (mean, pg/ml) } \\
\text { Premenopausal } \\
\text { Postmenopausal }\end{array}$ & $\begin{array}{l}18-60(38) \\
20-74(45)\end{array}$ & $\begin{array}{l}17-63(40) \\
18-67(47)\end{array}$ \\
\hline $\begin{array}{l}25(\mathrm{OH}) \text { vitamin D (mean, } \mathrm{ng} / \mathrm{ml}) \\
\text { Premenopausal } \\
\text { Postmenopausal }\end{array}$ & $\begin{array}{l}22-75(44.4) \\
20-72(40.1)\end{array}$ & $\begin{array}{l}21-76(42.3) \\
19-75(38.6)\end{array}$ \\
\hline $\begin{array}{l}\text { Serum CTx (mean, } \mathrm{ng} / \mathrm{ml} \text { ) } \\
\text { Premenopausal }^{*} \\
\text { Postmenopausal }^{* *}\end{array}$ & $\begin{array}{c}0.12-0.82(0.43) \\
0.2-1.62(1.1)\end{array}$ & $\begin{array}{l}0.056-0.41(0.27) \\
0.096-0.98(0.56)\end{array}$ \\
\hline $\begin{array}{l}\text { BSAP (mean, U/I) } \\
\text { Premenopausal }^{*} \\
\text { Postmenopausal }^{* *}\end{array}$ & $\begin{array}{l}13.8-38.6(23.8) \\
18.1-60.5(45.4)\end{array}$ & $\begin{array}{l}10.2-24.5(16.4) \\
13.4-40.3(25.2)\end{array}$ \\
\hline $\begin{array}{l}\text { Femoral neck BMD (mean, } \mathrm{g} / \mathrm{cm}^{2} \text { ) } \\
\text { Premenopausal }^{*} \\
\text { Postmenopausal }^{* *}\end{array}$ & $\begin{array}{c}0.8-1.29(1.04) \\
0.69-1.13(0.89)\end{array}$ & $\begin{array}{l}0.92-1.34(1.12) \\
0.82-1.22(1.02)\end{array}$ \\
\hline $\begin{array}{l}\text { Lumbar spine BMD (mean, } \mathrm{g} / \mathrm{cm}^{2} \text { ) } \\
\text { Premenopausal } \\
\text { Postmenopausal }^{*}\end{array}$ & $\begin{array}{c}0.92-1.43(1.17) \\
0.6-1.32(0.97)\end{array}$ & $\begin{array}{l}0.93-1.44(1.18) \\
0.73-1.49(1.09)\end{array}$ \\
\hline
\end{tabular}

SRS, symptom rating scale; LVMi, left ventricular mass index; E/A, maximal early diastolic flow velocity (E)/maximal late diastolic flow velocity (A); BMD, bone mineral density; BSAP, bone-specific alkaline phosphatase; CTx, carboxyterminal telopeptide. Values in the table are reported as range (minimum-maximum) (mean). $\mathrm{p}<$ $0.05 ;{ }^{* *} p<0.01$

cantly higher in patients with endogenous $\mathrm{SCH}$ (versus euthyroid subjects) demonstrates that this condition is not necessarily asymptomatic, in agreement with previous studies $(2,4)$, with the exception of one $(5)$.

Cardiac involvement, both morphological and affecting systolic and diastolic functions, was also observed with the LVMi, ejection fraction, E/A ratio and isovolumic relaxation time being significantly different in patients with SCH. Sgarbi e cols. (4) found a significant increase in LVMi but the $\mathrm{E} / \mathrm{A}$ ratio, isovolumic relaxation time and ejection fraction were not significantly different nor did they improve after the restoration of euthyroidism in the series studied (4). In order, the only echocardiographic feature detectable in patients with subclinical hyperthyroidism was an increased velocity of left ventricular relaxation (6). In contrast, 
Biondi e cols. (2) reported a clear difference between patients with endogenous $\mathrm{SCH}$ and euthyroid subjects for all cardiac parameters evaluated in the present study.

A reduction of BMD in postmenopausal women with $\mathrm{SCH}$ has been widely demonstrated (1). We also observed a significant increase in markers of bone formation (BSAP) and resorption (CTx) in premenopause women with SCH. In addition, BMD was lower in the femoral neck but not in the lumbar spine in these patients, whereas a lower BMD was observed at both sites in postmenopausal women with SCH. Similar results have been reported in other series of 60 women with endogenous SCH (30 pre- and 30 postmenopausal subjects) (7). In contrast, two studies showed that the bone mineral density of the lumbar spine, femoral neck and the midshaft of the radius were not significantly decreased in premenopausal patients with endogenous SCH and non increased bone turnover $(8,9)$.

The results show that endogenous $\mathrm{SCH}(\mathrm{TSH} \leq$ $0.1 \mathrm{mIU} / \mathrm{l})$ is not completely asymptomatic in women aged $<65$ years, and is associated with morphological and functional heart abnormalities and with increased bone turnover and reduced BMD even before menopause. These findings suggest that therapy should not be restricted to postmenopausal women or women older than 60 years $(1)$.

No potencial conflict of interest relevant to this article was reported.

\section{REFERENCES}

1. Cooper DS. Approach to the patient with subclinical hyperthyroidism. J Clin Endocrinol Metab. 2007;92:3-9.
2. Biondi $B$, Palmieri EA, Fazio $S$, Cosco $C$, Nocera $M$, Saccà $L$, et al. Endogenous subclinical hyperthyroidism affects quality of life and cardiac morphology and function in young and middle-aged patients. J Clin Endocrinol Metab. 2000;85:4701-5.

3. Devereux RB, Lutas EM, Casale PN, Kligfield P, Eisenberg RR, Hammond IW, et al. Standardization of M-mode echocardiographic left ventricular anatomic measurements. J Am Coll Cardiol. 1984; 4:1222-30.

4. Sgarbi JA, Villaça FG, Garbeline B, Villar HE, Romaldini JH. The effects of early antithyroid therapy for endogenous subclinical hyperthyroidism in clinical and heart abnormalities. $J$ Clin Endocrinol Metabol. 2003;88:1672-7.

5. Schlote B, Schaaf L, Schmidt R, Pohl T, Vardarli I, Schiebeler H, et al. Mental and physical state in subclinical hyperthyroidism: investigations in a normal working population. Biol Psychiatry. 1992;32:48-56.

6. Petretta M, Bonaduce D, Spinelli L, Vicario ML, Nuzzo V, Marciano F, et al. Cardiovascular haemodynamics and cardiac autonomic control in patients with subclinical and overt hyperthyroidism. Eur J Endocrinol. 2001;145:691-6.

7. Tauchmanovà L, Nuzzo V, Del Puente A, Fonderico F, EspositoDel Puente A, Padulla S, et al. Reduced bone mass detected by bone quantitative ultrasonometry and DEXA in pre- and postmenopausal women with endogenous subclinical hyperthyroidism. Maturitas. 2004;48:299-306.

8. Foldes J, Tarjan G, Szathmary M, Varga F, Krasznai I, Horvath C. Bone mineral density in patients with endogenous subclinical hyperthyroidism: is the thyroid status a risk factor for osteoporosis? Clin Endocrinol (Oxf). 1993;39:521-7.

9. Gurlek A, Gedik O. Effect of endogenous subclinical hyperthyroidism on bone metabolism and bone mineral density in premenopausal women. Thyroid. 1999;9:539-43.

\section{Correspondence to:}

Pedro Weslley Rosario

Centro de Estudos e Pesquisa da Clínica de Endocrinologia e Metabologia (CEPCEM)

Av. Francisco Sales, 1111 , $5^{\circ}$ D, Santa Efigênia

30150-221 Belo Horizonte MG

E-mail: pedrorosario@globo.com 